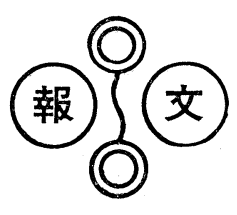

コークスの光学的異方性組織と ガス化反応性

-1981.2 .17 受理一

三井鉱山秼) 木庭敬一郎 - 坂田康二・井田四郎

\section{1.まえがき}

コークスのソリューションロス反応は光学的異方性 組織を不均一に侵蝕し, 光学的異方性の低い組織が選 択的に損耗していくことが高炉解体調查の結果 ${ }^{122)} や$ 実験室的な研究結果 ${ }^{8) \sim 5)}$ から報告されてきた。筆者ら も小型のレトルトで作った各種単味コークスならびに 実用の高炉用コークスを用いて $\mathrm{H}_{2} \mathrm{O}$ 抢よび $\mathrm{CO}_{2}$ と の反応性について研究を行い, 前述のような傾向を確 認し, さらに $\mathrm{H}_{2} \mathrm{O}$ との反応では光学的異方性組織に 対する選択性が大きいことと, その選択性は炭種によ

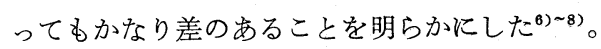

このように光学的異方性組織はコークスの反応性を 論ずるらえで重要な意味を持つにもかかわらず, 光学 的異方性組織そのものの反応性を定量的倫じた研究 は少なく, 最近西田らの)によってその定量的測定が試 及始められたが, 光学的組織の反応性の定量的な解明 はまだ十分とは言えない。

コークスの各光学的異方性組織の反応性に加成性が 成立すると仮定すれば, 各光学的組織ごとの反応性の 和としてコークスの反応性は推定できる。しかしコー クスの反応性を支配する要因は複雑で, 光学的組織の 添かに含有する扊分の触媒活性や, 気孔率, 比表面積 などの物理的性状にも影響を受ける。したがって雪分 や物理的構造の異なる異炭種からのコークスを用いて 光学的組織の反応性を比較し, 定量的に論じることは 容易ではない。るし物理的構造がなるべく近似し, 光 学的異方性組織のみをことにするコークスを作成する ことがでさるならば, それらのコークスを用いて光学 的組織の反応性とコークスの反応性との関係の定量性 を向上できよう。本報告は同一原炭を雾囲気圧力を变 觉て炭化することにより光学的異方性組織を修飾 ${ }^{10) 111}$ したコークスを作成し，それらのコークスを用いて各 光学的組織の反応性を定量的に記述し、コークスの反 応性の推定を試みたものである。

北九州事業所 北九州市若松区響町1-3

\section{2. 実 験}

\section{1 試 料}

供試石炭は Table 1 飞示すように, 石炭の平均反射 率を0.74〜1.72\%,イナーチニット含有量を $2.6 \sim 35.8$ \%の範囲で10種類を選んだ。試料炭は $3 \mathrm{~mm}$ 以下に粉 砕後, 約 $200 \mathrm{~g}$ を $80 \mathrm{~mm} \phi \times 200 \mathrm{~mm}$ の鋼製レトルト に入れ，電気炉外熱によりコークス化する。加熱条件 は昇温速度 $200^{\circ} \mathrm{C} / \mathrm{h}$, 試料の最終温度およびその保持 時間を $950^{\circ} \mathrm{C}, 2$ 時間とした。

炭化時の䨌囲気圧力は $30 \mathrm{mmHg}$ の減圧, 常圧およ び $100 \mathrm{~kg} / \mathrm{cm}^{2}$ の加圧の 3 水準をとった。減圧炭化沶 よび常圧炭化の場合は，前述の鋼製レトルトを用いて 常温から最終温度まで炭化した。常圧を維持するため には発生ガスをその立大気放出とし，隇圧炭化では 真空ポンプによりレトルト内圧力を $30 \mathrm{mmHg}$ に保 持しながら炭化する。加压炭化の場合には, 第一段階 としてまずオートクレーブ中で $100 \mathrm{~kg} / \mathrm{cm}^{2}$ の加圧下 に $200^{\circ} \mathrm{C} / \mathrm{h}$ の昇温速度で $500^{\circ} \mathrm{C} て ゙$ 加熱し, 光学的異 方性組織の展開を固定させたのち, いったん放冷し炭 化物を取り出し, 次いで前述の鋼製レトルトに移して ふたたび常圧下で $200^{\circ} \mathrm{C} / \mathrm{h}$ で $950^{\circ} \mathrm{C}$ む゙昇温し， 2 時 間保持してコークス化を完了する二段階方式をとっ た。

2.2 コークスの比表面積, 気孔容積の測定

コークスの BET 比表面積は $300^{\circ} \mathrm{C} て ゙ 1$ 時間脱ガス 後島津 Sorptograph ADS-1B を用いて測定した。吸 着ガスには $\mathrm{CO}_{2}$ を用い, 相対圧 $(\mathrm{P} / \mathrm{Po})$ は約 0.25 と して $-74^{\circ} \mathrm{C}$ 亿和ける吸着量を求める。吸着平衡時間は 2 時間とした。

$$
\mathrm{S}=\frac{\mathrm{n} \sigma \mathrm{Vm}}{\mathrm{W}}
$$

$\mathrm{S}=$ 比表面積 $\left(\mathrm{m}^{2} / \mathrm{g}\right)$

$\mathrm{n}=1 \mathrm{~m} l$ 中に存在する吸着ガス分子の数(個 $/ \mathrm{m} l$ )

$\sigma=$ 吸着ガス 1 分子の占有面積 $\left(14.1 \AA^{2}\right)^{12)}$

$\mathrm{Vm}=$ 単分子層吸着のガス量 $(\mathrm{m} l)$

$\mathrm{W}=$ 試料コークス重量 $(\mathrm{g})$ 


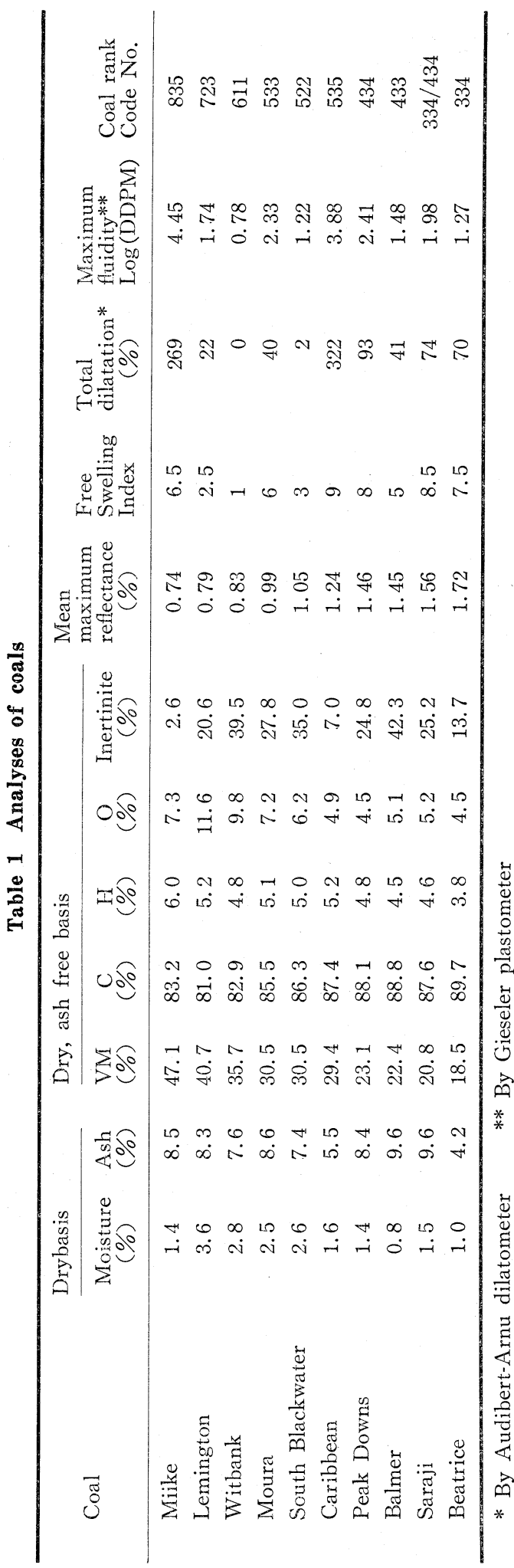

半径 $50 \mu \mathrm{m} \sim 50 \AA$ 範围の細孔分布は島津 Micro meritics Mercury Penetration Porosimeter 905-1 型を用いて測定した。(2)式にしたがって細孔径別の比 表面積を求めた。

$$
\triangle S=\frac{2 \triangle V}{\gamma m}
$$

$\triangle \mathrm{V}=$ ある細孔々径匴囲の細孔容積 $\left(\mathrm{m}^{3} / \mathrm{g}\right)$

$\gamma \mathrm{m}=\Delta \mathrm{V}$ K相当する平均細孔半径 $(\mathrm{m})$

$\triangle S=\triangle V$ に相当する比表面積 $\left(\mathrm{m}^{2} / \mathrm{g}\right)$

反応性測定之同じ粒度の試料コークスを用いて気孔 容積を測定した。試料を蒸留水中に浸し，十分に煮沸 して完全に気孔中の空気を追い出し放冷して気孔に完 全漫水させた後，含水試料の重量を測定する。別同 試料の乾燥重量を測定し(3)式によって気孔容積を算出 する。

$$
\mathrm{V}=\frac{\mathrm{W}_{2}-\mathrm{W}_{1}}{\mathrm{~W}_{1}}
$$

$\mathrm{V}=$ 気孔容積 $(\mathrm{m} l / \mathrm{g})$

$\mathrm{W}_{1}=$ 乾燥試料重量 $(\mathrm{g})$

$\mathrm{W}_{2}=$ 含水試料重量 $(\mathrm{g})$

\section{3 反応性の測定}

コークスの反応性の測定には前に報告6) したと同じ 装置を使用した。供試コークスは 3 6 $\mathrm{mm}$ に整粒し, $10 \mathrm{~g}$ を白金バスケットに入れ反応管内につるし，常圧 下に $2 \mathrm{l} / \mathrm{min}$ の反応ガス $\left(\mathrm{CO}_{2}\right.$ また快 $\left.\mathrm{H}_{2} \mathrm{O}\right)$ を流通 させながら $1,200^{\circ} \mathrm{C}$ で反応させる。反応によるコーク スの重量減少を連続的に記録し，(4)式に上って反応速 度を算出する。反応は $50 \%$ 重量減少に達するまで行 万。

$$
\mathrm{k}=\frac{\mathrm{W}_{\mathrm{b}}-\mathrm{W}_{\mathrm{a}}}{\mathrm{W}_{\mathrm{b}}} \times \frac{1}{\mathrm{t}}
$$

$$
\begin{aligned}
\mathrm{W}_{\mathrm{b}} & =\text { 反応前のコークス重量 (daf. } \mathrm{g}) \\
\mathrm{W}_{\mathrm{a}} & =\text { 反応後のコークス重量 (daf. } \mathrm{g}) \\
\mathrm{t} & =\text { 反応に要した時間 }(\mathrm{min}) \\
\mathrm{k} & =\text { ニークスの反応速度 }(\mathrm{g} / \mathrm{g} \cdot \mathrm{min})
\end{aligned}
$$

2.4 光学的異方性組織の定量と反応性の算出 供試コークスは反応前と $50 \%$ 重量減少した反応後と に，常法にしたがい樹脂に埋め込み，研磨面を偏光顕 微鏡下に約 700 点をポイントカウントし, 光学的異方 性組織の分布を定量した。コークスの光学的組織の分 類は前報8)にしたがうこととしたが，Semifusinitelike, Fusinitelike, Micrinitelike texture はすべてイ ナート組織に一括した。各光学的組織ごとの反応性は (5)式によって算出する。 


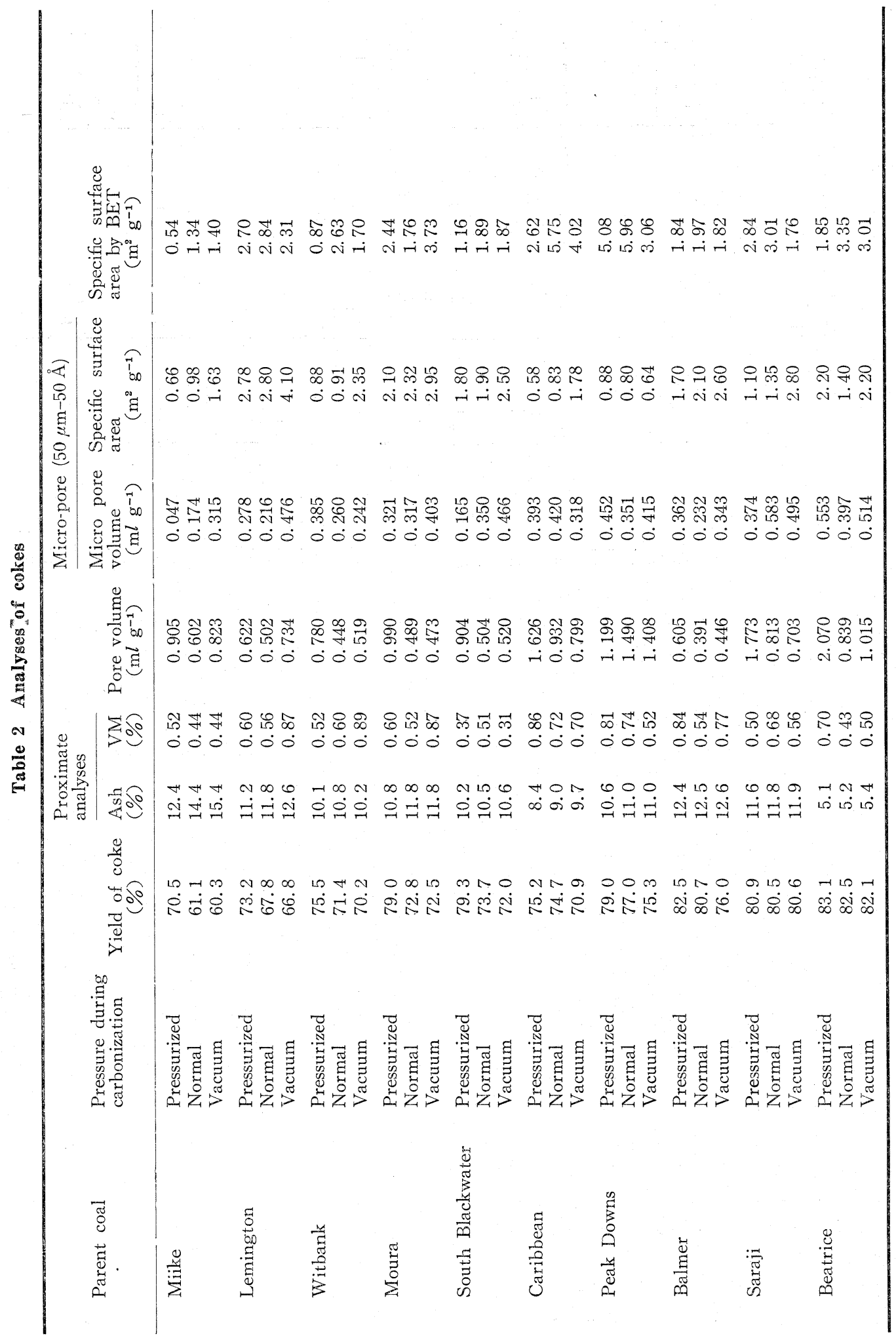




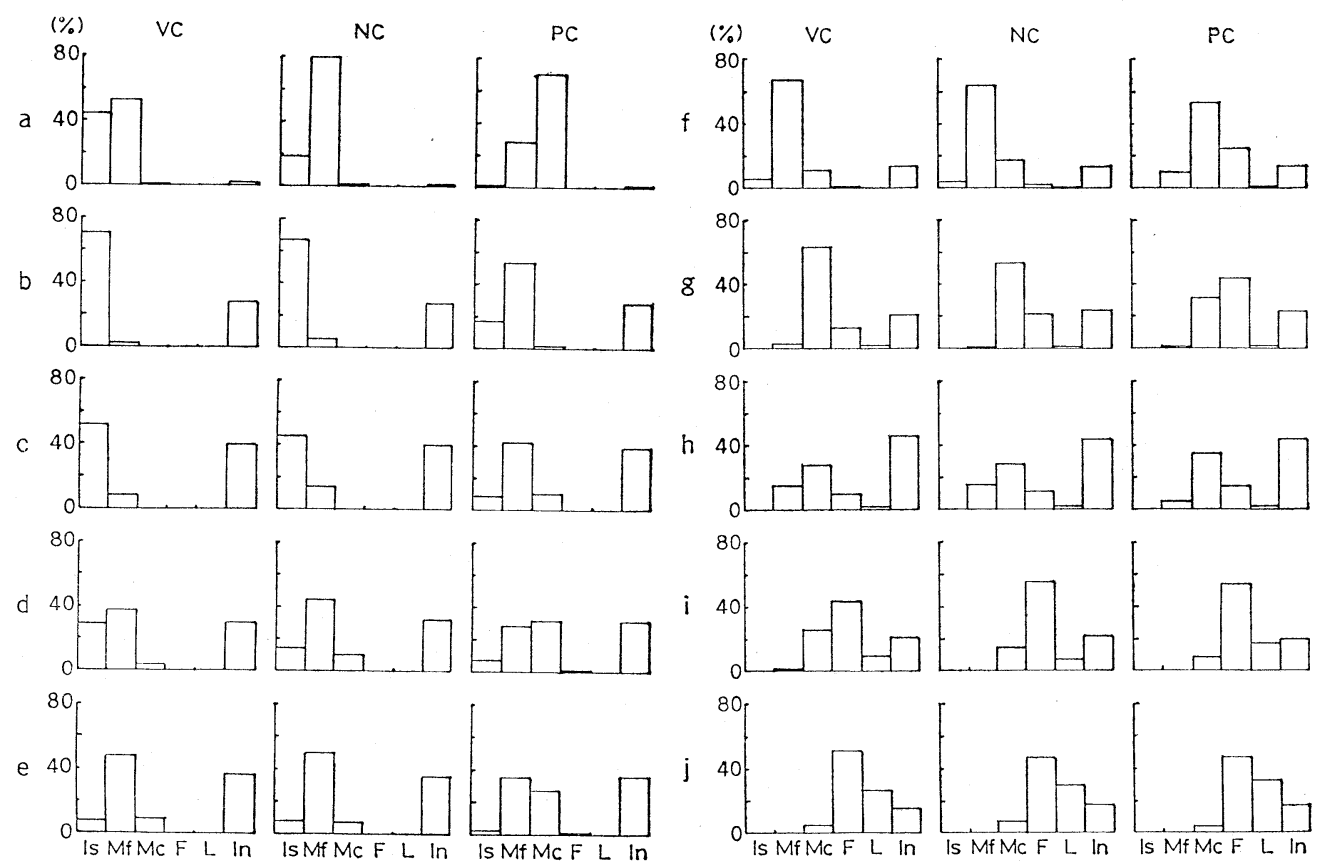

VC : Vacuum carbonization coke, $\mathrm{NC}:$ Normal carbonization coke, PC : Pressurized carbonization coke, Is : Isotropic texture, Mf : Fine mosaic texture, Mc : Coarse mosaic texture, F : Fibrous texture, L : Leafet texture, In : Inert texture, $\mathrm{a}:$ Miike, $\mathrm{b}:$ Lemington, $\mathrm{c}:$ Witbank, $\mathrm{d}:$ Moura, e : South Blackwater, f: Caribbean, $\mathrm{g}:$ Peak Downs, $\mathrm{h}:$ Balmer, i : Saraji, $\mathrm{j}$ : Beatrice

Fig. 1 Histogram of optical textures of cokes obtained under vacuum, normal and pressuried carbonization

$$
\mathrm{k}_{\mathrm{i}}=\frac{\mathrm{W}_{\mathrm{a}} \times \mathrm{C}_{\mathrm{ia}}}{\mathrm{W}_{\mathrm{b}} \times \mathrm{C}_{\mathrm{ib}}} \times \frac{1}{\mathrm{t}}
$$

$\mathrm{C}_{\mathrm{ib}}$ =反応前コークス中の $\mathrm{i}$ 組織の分布率

$\mathrm{C}_{\mathrm{i} \mathrm{a}}=$ 反応後コークス中の $\mathrm{i}$ 組織の分布率

$\mathrm{k}_{\mathrm{i}}=\mathrm{i}$ 組織の反応速度 $(\mathrm{g} / \mathrm{g} \cdot \mathrm{min})$

\section{3. 実 験 結 果}

3.1 コークスの性状と光学的異方性組織

生成コークスの気孔容積, 細孔容積(半径 $50 \mu \mathrm{m} \sim 50$

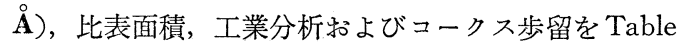
2 に示す。炭化時の圧力が高いほどコークスの歩留は 高いといら傾向が明りょうに認められ，この傾向は石 炭化度の低い石炭活ど顕著で, 石炭化度の高い石炭で は僅少である。これは本来揮発分となるべき部分が加 圧炭化ではコークスとして残留し, 減圧炭化では常圧 炭化以上に揮発して失われたことを意味する。灰分は コークス歩留りの変化に見合って若干の增減が見ら れる。コークス揮発分はいずれも $1 \%$ 以下になってお
り、コークス化は十分に行われていることがわかる。

Table 2 に見られるよらに，同一原炭を原料とする コークスであっても, 炭化圧力の違いによってその物 理的性状にはかなりの違いが見られた。加圧炭化コー クスの気孔容積は常圧炭化コークスのそれより大きく なる傾向がかなり明りょらであるのに対し, 減圧炭化 による気孔容積の変化には明確な傾向が認めがたい。 BET 比表面積は, 原炭の種類掞よび炭化圧力によっ てかなり異なった值を示すが，炭化圧力との間汇一 定の関係を見いだせない。水銀ポロシメーター測定に よる半径 $50 \mu \mathrm{m} \sim 50 \AA$ の細孔容積で恃炭化圧力との関 係は明らかでないが， $50 \mu \mathrm{m} \sim 50 \AA$ の比表面積は，一 部の例外を除いて，減圧炭化コークスのそれが顕著な 増大をしているのが認められる。 $50 \mu \mathrm{m} \sim 50 \AA$ の比表 面積と BET 比表面積とは必ずしも比例関係にはなく, 比較的良く一致しているものもあるが，Caribbean や Peak Downs のように大きな差を示するのもある。 
Table 3 Gasification reactivities of cokes $\left(\mathrm{g} \mathrm{g}^{-1} \mathrm{~min}^{-1} \times 10^{2}\right)$

\begin{tabular}{|c|c|c|c|c|c|c|c|c|c|}
\hline \multirow{3}{*}{ Parent coal } & \multirow{3}{*}{$\begin{array}{l}\text { Pressure } \\
\text { During } \\
\text { Carbonization }\end{array}$} & \multicolumn{4}{|c|}{ With $\mathrm{CO}_{2}$} & \multicolumn{4}{|c|}{ With $\mathrm{H}_{2} \mathrm{O}$} \\
\hline & & \multicolumn{4}{|c|}{ Gasification ratio $(\%)$} & \multicolumn{4}{|c|}{ Gasification ratio $(\%)$} \\
\hline & & 10 & 20 & 30 & 50 & 10 & 20 & 30 & 50 \\
\hline \multirow[t]{3}{*}{ Miike } & Pressurized & 2.15 & 2.29 & 2.33 & 2.31 & 3.60 & 3.74 & 3.79 & 3.72 \\
\hline & Normal & 1.94 & 2.09 & 2.16 & 2.19 & 3.45 & 3.50 & 3.52 & 3.45 \\
\hline & Vacuum & 2.57 & 2.73 & 2.75 & 2.69 & 3.92 & 4.13 & 4.19 & 4. 12 \\
\hline \multirow[t]{3}{*}{ Lemington } & Pressurized & 1.59 & 1.50 & 1.50 & 1.31 & 3.57 & 3.77 & 3.83 & 3.68 \\
\hline & Normal & 2.06 & 2.05 & 1.98 & 1.76 & 3.85 & 4.08 & 4.12 & 4.04 \\
\hline & Vacuum & 2.63 & 2.62 & 2.56 & 2.36 & 4.42 & 4.53 & 4.56 & 4.51 \\
\hline \multirow[t]{3}{*}{ Witbank } & Pressurized & 1.75 & 1.72 & 1.67 & 1.52 & 3.39 & 3.50 & 3.57 & 3.50 \\
\hline & Normal & 1.71 & 1.74 & 1.73 & 1.63 & 3.81 & 4.03 & 4.04 & 3.97 \\
\hline & Vacuum & 1.90 & 1.96 & 1.96 & 1.87 & 4.06 & 4.28 & 4.33 & 4.24 \\
\hline \multirow[t]{3}{*}{ Moura } & Pressurized & 2.16 & 2.11 & 2.03 & 1.82 & 4.03 & 4.04 & 3.92 & 3.67 \\
\hline & Normal & 2.29 & 2.19 & 2.11 & 1.86 & 4.36 & 4.24 & 4.13 & 3.80 \\
\hline & Vacuum & 2.76 & 2.60 & 2.46 & 2.14 & 4.26 & 4.43 & 4. 41 & 4.19 \\
\hline \multirow[t]{3}{*}{ South Blackwater } & Pressurized & 1.93 & 1.91 & 1.84 & 1.63 & 3.66 & 3.67 & 3.65 & 3.42 \\
\hline & Normal & 2.04 & 1.97 & 1.87 & 1.65 & 3.90 & 4.01 & 3.92 & 3.66 \\
\hline & Vacuum & 2.34 & 2.30 & 2.21 & 1.99 & 4.34 & 4.44 & 4.37 & 4. 11 \\
\hline \multirow[t]{3}{*}{ Caribbean } & Pressurized & 1.37 & 1.41 & 1.39 & 1.31 & 4.73 & 4.87 & 4.92 & 4.73 \\
\hline & Normal & 2.40 & 2.46 & 2.42 & 2.27 & 3.91 & 4.00 & 4.02 & 3.83 \\
\hline & Vacuum & 2.30 & 2.46 & 2.50 & 2.44 & 4.42 & 4.62 & 4.63 & 4.46 \\
\hline \multirow[t]{3}{*}{ Peak Downs } & Pressurized & 0.89 & 0.92 & 0.91 & 0.86 & 2.20 & 2.33 & 2.35 & 2.25 \\
\hline & Normal & 1.04 & 1.01 & 0.96 & 0.87 & 2.20 & 2.16 & 2.04 & 1.80 \\
\hline & Vacuum & 1.19 & 1.16 & 1.10 & 0.96 & 2.51 & 2.51 & 2.42 & 2.11 \\
\hline \multirow[t]{3}{*}{ Balmer } & Pressurized & 1.25 & 1.25 & 1.20 & 1.05 & 2.92 & 2.91 & 2.81 & 2.53 \\
\hline & Normal & 1.54 & 1.43 & 1.34 & 1.12 & 3.12 & 3.10 & 2.91 & 2.54 \\
\hline & Vacuum & 1.55 & 1.47 & 1.36 & 1.13 & 3.36 & 3.29 & 3.14 & 2.78 \\
\hline \multirow[t]{3}{*}{ Saraji } & Pressurized & 1.19 & 1.20 & 1.17 & 1.05 & 2.74 & 2.85 & 2.83 & 2.69 \\
\hline & Normal & 1.17 & 1.09 & 1.01 & 0.86 & 2.46 & 2.40 & 2.21 & 1.88 \\
\hline & Vacuum & 1.21 & 1.11 & 1.04 & 0.90 & 2.45 & 2.25 & 2.08 & 1.74 \\
\hline \multirow[t]{3}{*}{ Beatrice } & Pressurized & 2.34 & 2.34 & 2.30 & 2.16 & 3.71 & 3.66 & 3.59 & 3.44 \\
\hline & Normal & 1.61 & 1.62 & 1.60 & 1.52 & 2.65 & 2.61 & 2.53 & 2.43 \\
\hline & Vacuum & 1.80 & 1.78 & 1.72 & 1.59 & 3.18 & 2.90 & 2.67 & 2.43 \\
\hline
\end{tabular}

コークスの各光学的異方性組織分布率の測定結果を ヒストグラムにして Fig.1に示す。イナート組織の分 布率は炭化圧力にはまったく関係なく，原炭によって 定まるが，リアクテイブ由来の組織は期待どおり，炭 化圧力の変化によってその光学的異方性は大きく修飾 されている。すなわら, 炭化圧力の上昇によって光学 的異方性は著しく向上の方向に向から。この傾向は石 炭化度の低い石炭汪ど顕著で，石炭化度の高い石炭で
は僅少である。

\section{2 コークスのガス化反応性}

Table 3 は，コークスの $\mathrm{CO}_{2}$ ならびに $\mathrm{H}_{2} \mathrm{O}$ による ガス化反応速度の測定結果である。反応速度は重量減 少率 (反応率) が10，20，30扎よび50\%に達するまで の反応速度で表わした。ガス化反応によるコークスの 重量減少の過程は, 経時的には固体の分解反応で見ら れるよらにまず最初に短いながら誘導期があって， 


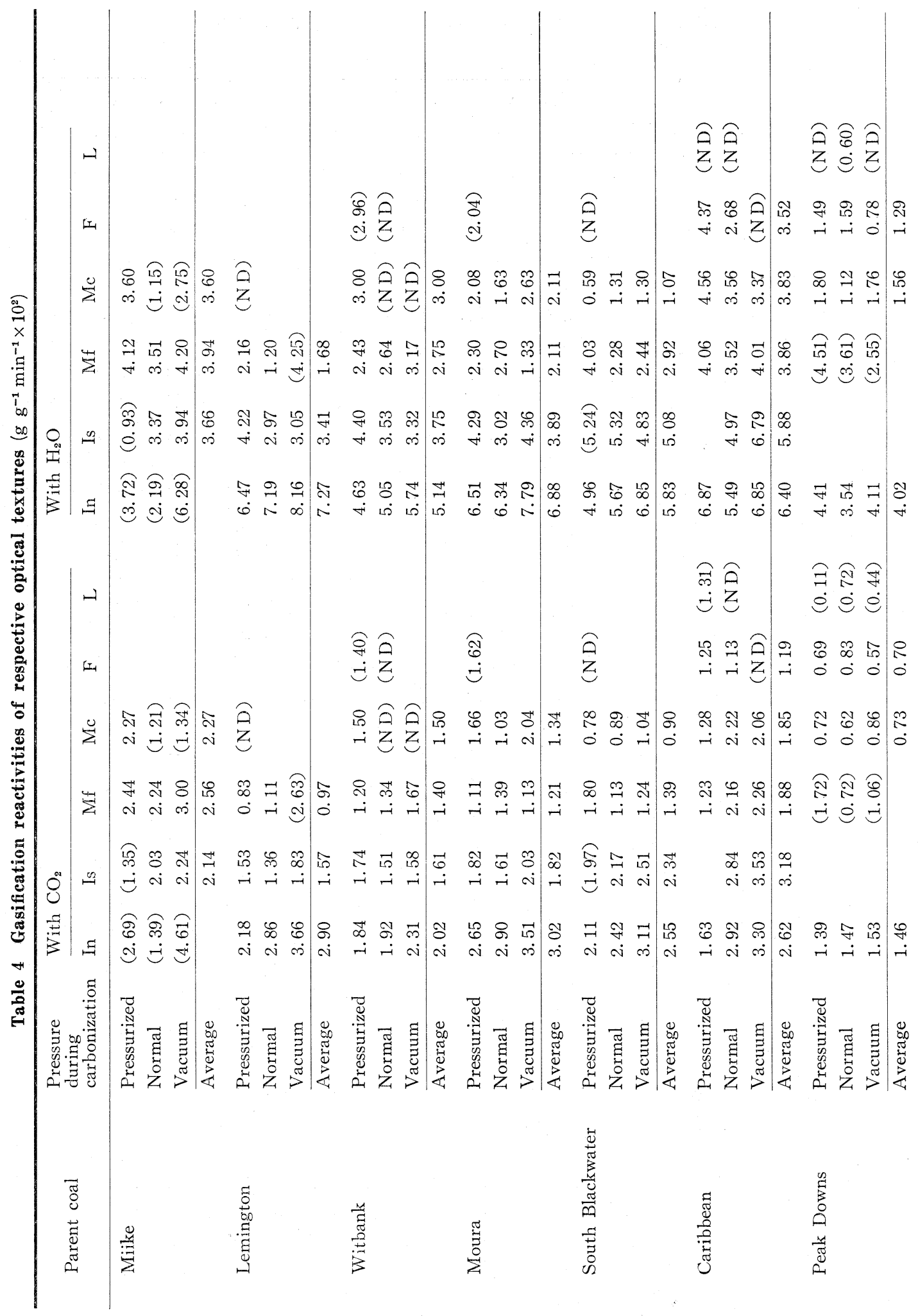




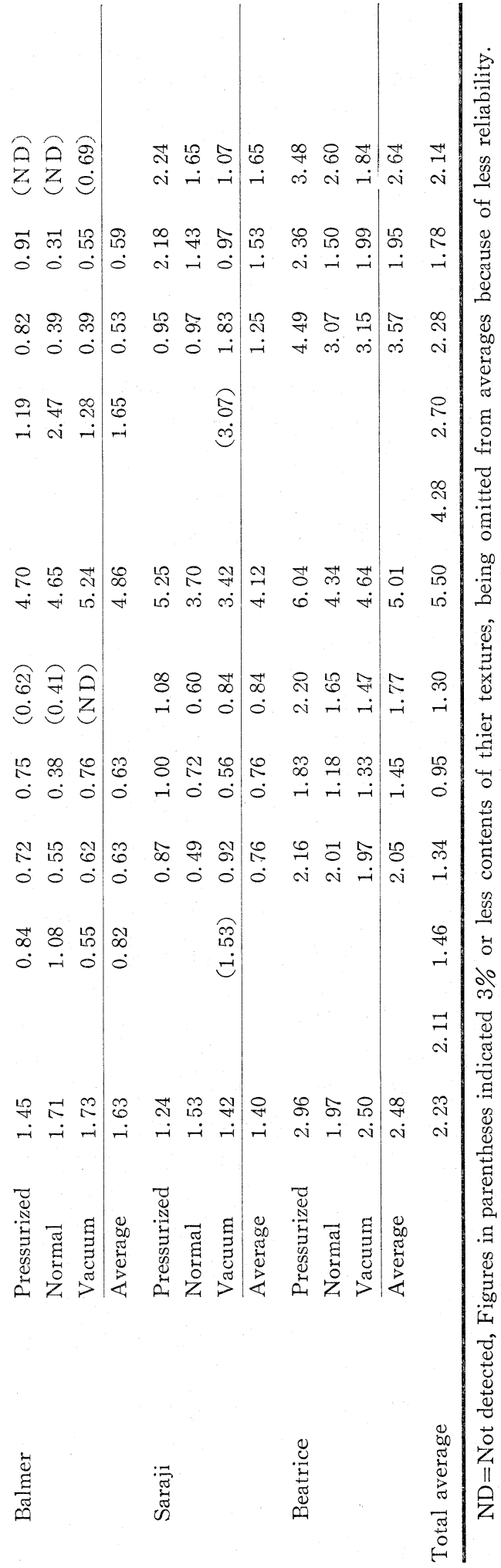

つぎに加速期, 終了期と続くゆるやかな $\mathrm{S}$ 字型のカー ブを描く。50\%反応率の時点は, 若干終了期に入りか けたところに当たる。

前報象8) 飞る述べたようと, $\mathrm{H}_{2} \mathrm{O}$ との反応性は $\mathrm{CO}_{2}$ とのそ机より大き值を示し, 香た炭種, 岸化圧力に 上る差も大きい。 $\mathrm{CO}_{2}$ との反応性の大きいコークスは $\mathrm{H}_{2} \mathrm{O}$ との反応性子やはり高いといら一般的傾向は西 るものの, $\mathrm{CO}_{2}$ との反応速度の大きさの順位と $\mathrm{H}_{2} \mathrm{O}$ との反応速度の順位とは必ずしも一致しない。たと兄 ば, $\mathrm{CO}_{2}$ との反応性ではもっとも高いグループの三池 が, $\mathrm{H}_{2} \mathrm{O}$ との反応性ではその順位はかなり下がる。

$\mathrm{CO}_{2}$ との反応性は, 比較的高反応性レベルの崖種 では三池炭を除いて, Lemington, Moura 特よび Caribbean で炭化压力の上昇飞よる反応性の低下傾向 が明りように認められるのに詨し, 低反応性レベルの 炭種ではやや不明りょうとなる。一力，三池，Saraji Beatriceのように, その石炭化度に比較して膨張性の 高い石炭の場合, か党って加圧炭化コークスの反応性 が上昇しているものもある。 $\mathrm{H}_{2} \mathrm{O}$ との反応性でも, 加 熱溶融時の膨張性の低い炭種は炭化圧力の上昇がコー クスの反応性低下につながるのに比べ，膨張情の高い 炭種 (三池, Caribbean, Peak Downs, Saraji, Beatrice) の加王炭化コークスの反応性は明らかに増 大傾向を示している。

コークスのガス化反応の時間的経過の中で, 反応速 度と比表面積がどのような関係市るかを, 実用の高 炉用コークスを用いて調べた結果が Fig.2である。こ の場合の反応速度は各反応時点における瞬間の反応速 度で表わした。反応速度は反応率10\%付近まではすみ やかに，その後もゆるやかに上昇を続ける。 $\mathrm{H}_{2} \mathrm{O}$ との 反応では反応率が $30 \%$ を越光てからの反応速度の上昇 傾向がやや大きい。コークスの比表面積は反応前は僅 か $0.6 \mathrm{~m}^{2} / \mathrm{g}$ であったのが，西ス化反応によって急速に 増大し, 反応率 $10 \%$ 時点では約 10 倍以上に達する。 $\mathrm{CO}_{2}$ との反応では, 反応率10３0\%間では比表面積は あまり変化しない。それを越劣る之若干減少傾向にな る。 $\mathrm{H}_{2} \mathrm{O}$ との反応では, $\mathrm{CO}_{2}$ の場合より比表面積の 増大幅は大きい。乙かし反応率が30\%を越光ると比表 面積は急速に低下し，40\%以上では $\mathrm{CO}_{2}$ との反応よ りか党って小さくなる。

\section{3 光学的異方性組織のガス化反応性}

光学的組織のガス化反応性の定量汇は 2 つの方法を 用いた。第 1 の方法では, ガス化反応前のコークスと 50\%重量減少まで反応させたあとのコークスについて 求めた光学的組織の分布率を用いて, (5)式から各光学 


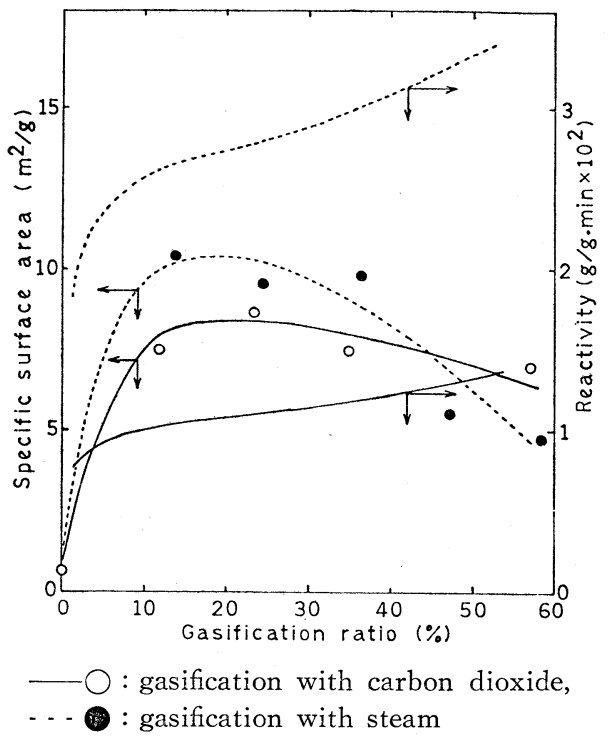

Fig. 2 Specific surface area of a metallurgical coke during gasification with carbon dioxide and steam

的組織ごとに反応速度を算出した( I 法)。一方，ここ に得られた30組の反応速度のデータから，反応前コー クスの光学的組織の分布量を独立変数とし，コークス の反応速度を従属变数とする回帰分析を行い, 光学的 組織の反応速度を統計的に，平均值として推定する方 法が考えられる(II法)。この方法による光学的組織の 反応性は，灰分の触楳作用やュークスの物理的性状あ るいは炭種による差などをすべて無視して，まったく 平均值として求めるものである。しかし，こらした方 法でも合理的な数值が求めらるのかどらか, また求め らるならばその数値は I 法による実測値と比較してど らなのかは，I法の值をチェックする意味でも十分検 討に值しよう。

I 法による結果をTable 4 に示す。ただし，光学的 組織の分布率が非常に低い場合にはその測定精度は低 く, したがってその光学的組織の反応速度の精度も低 いと考えられるため, Table 4 ではそれらの值は括弧 に入れ区別して示し, 平均值の算出からは除外した。 若干の例外を除けば，同じ原炭から異なった圧力下で 形成された同一組織の反応性は多少のばらつきはある ものの, 比較的近似した值を示している。異炭種間で はそのばらつきは拡大するが，同一組織ごとにまとめ て全平均值を算出し，Table 4 の最下欄に記載した。

II法による計算結果を Table 5 に示す。最初に通常 の最小二乗法によって回帰式を求めた（式No. 1 4)。
計算結果は各係数の值のばらつきが大きく，一部には マイナスの值も得られ，妥当とは言えない。そこでコ 一クスの反応速度は光学的組織の反応速度の加重平均 であると考えて，定数項をゼ口と和く最小二乗法によ って回帰式を求めた（式 No. 5〜8）。こうして求めた 独立変数の各係数は, それぞれの光学的組織の反応性 に相当するはずである。 $\mathrm{H}_{2} \mathrm{O}$ との反応性については, I 法で求めた光学的組織の反応性に拈括むね適合する 值が得られたが, $\mathrm{CO}_{2}$ との反応性では，な拉一部の係 数はマイナスとなり実際とは矛盾する結果となった。 そこでさらに，各係数はマイナスにならないといら仮 定を加えて回帰分析を行った（式No.9〜12）。この方 法で得られた各組織の反応性指数とI 法から算出した 反応速度とを比較してみると，回帰分析で求められた 值の方が葉片状組織で高く, イナート組織で低いこと を除けば両者の值はかなり良く一致して和り，一応妥 当といえよう。

\section{4. 若 察}

4.1 コークスの光学的異方性組織と物理的性状に 対する炭化压力の影響

石炭からコークスを生成するには，加熱時に溶融過 程を経ることが必須条件であり，そしてこの溶融時か ら再固化時までにおこる諸反応がコークスの性状を決 定する。溶融状態にある間に，石炭分子はガスを放出 しながら重縮合をおこし，高分子化が進んでいく。石 炭の熱溶融相 (matrix) の流動性は温度上昇とともに, いったんは大きくなるが，高分子化が進んでくると粘 度が上がり, やがて流動性を失なって再固化しコーク スとなる。この時の matrix の粘度, 構成分子の大き さと形状, ガスの発生状況などの間の諸関係によっ て, 得られるコークスの性状が決定される。

H. Marsh ${ }^{13)}$ は石炭の炭化に打いて光学的異方性組 織が発現するためには, 次の二つの条件が必要である としている。第一の条件は，加熱下の重縮合反応によ って matrix を棈成している分子が，適当な大きさを 持ち，かつ配向性の良い重層構造に重なり合らことが できる形状(平面状)の分子に成長できることであり， 第二は，炭化を受けている間， matrix 全体が十分な 流動性を持ち, 分子が重層構造を形成する運動が十分 にできることである。

加圧下に炭化される場合には揮発分の離脱が抑制さ れ, 逆に減圧下の炭化では揮発分の離脱が促進され る。このことはコークスの歩留が, 加圧炭化>常圧炭 化>減圧炭化の順序に正しく並んでいることから肯定 される。揮発分は石炭構成分子のらち, 比較的分子量 
Table 5 Regression analyses on reactivities of optical textures

\begin{tabular}{|c|c|c|c|}
\hline No. & Regression equations & $\mathrm{F}$ & Gasification ratios \\
\hline \multicolumn{4}{|c|}{ Reactivities with carbon dioxide } \\
\hline 1 & $\mathrm{y}=-2.77 \mathrm{x}_{1}-2.94 \mathrm{x}_{2}-3.77 \mathrm{x}_{3}-5.21 \mathrm{x}_{4}-0.32 \mathrm{x}_{6}-4.27 \mathrm{x}_{6}+5.44$ & 8.37 & $10 \%$ \\
\hline 2 & $\mathrm{y}=3.66 \mathrm{x}_{1}+3.42 \mathrm{x}_{2}+2.83 \mathrm{x}_{3}+0.71 \mathrm{x}_{4}+6.52 \mathrm{x}_{6}+1.79 \mathrm{x}_{6}-0.86$ & 14.21 & $20 \%$ \\
\hline 3 & $y=3.51 x_{1}+3.28 x_{2}+2.67 x_{8}+0.53 x_{4}+6.36 x_{8}+1.42 x_{6}-0.69$ & 16.45 & $30 \%$ \\
\hline 4 & $y=2.96 x_{1}+2.74 x_{2}+2.14 x_{3}+0.05 x_{4}+5.74 x_{0}+0.54 x_{0}-0.21$ & 19.05 & $50 \%$ \\
\hline 5 & $y=2.59 x_{1}+2.47 x_{2}+1.78 x_{3}-0.19 x_{4}+5.68 x_{6}+1.35 x_{6}$ & 10.03 & $10 \%$ \\
\hline 6 & $\mathrm{y}=2.75 \mathrm{x}_{1}+2.58 \mathrm{x}_{2}+1.90 \mathrm{x}_{3}-0.18 \mathrm{x}_{4}+5.83 \mathrm{x}_{6}+1.02 \mathrm{x}_{6}$ & 12.50 & $20 \%$ \\
\hline 7 & $\mathrm{y}=2.78 \mathrm{x}_{1}+2.61 \mathrm{x}_{2}+1.91 \mathrm{x}_{8}-0.18 \mathrm{x}_{4}+5.82 \mathrm{x}_{6}+0.79 \mathrm{x}_{6}$ & 15.15 & $30 \%$ \\
\hline 8 & $\mathrm{y}=2.74 \mathrm{x}_{1}+2.55 \mathrm{x}_{2}+1.89 \mathrm{x}_{3}-0.16 \mathrm{x}_{4}+5.62 \mathrm{x}_{\mathrm{B}}+0.34 \mathrm{x}_{6}$ & 17.45 & $50 \%$ \\
\hline 9 & $\mathrm{y}=2.77 \mathrm{x}_{1}+2.54 \mathrm{x}_{2}+1.60 \mathrm{x}_{3}+0.70 \mathrm{x}_{4}+3.31 \mathrm{x}_{6}+1.16 \mathrm{x}_{6}$ & 7.52 & $10 \%$ \\
\hline 10 & $y=2.60 x_{1}+2.66 x_{2}+1.47 x_{3}+0.95 x_{4}+3.08 x_{5}+1.17 x_{6}$ & 6.97 & $20 \%$ \\
\hline 11 & $\mathrm{y}=2.72 \mathrm{x}_{1}+2.68 \mathrm{x}_{2}+1.50 \mathrm{x}_{3}+0.82 \mathrm{x}_{4}+3.34 \mathrm{x}_{5}+0.94 \mathrm{x}_{6}$ & 9.42 & $30 \%$ \\
\hline 12 & $\mathrm{y}=2.68 \mathrm{x}_{1}+2.48 \mathrm{x}_{2}+1.50 \mathrm{x}_{3}+0.71 \mathrm{x}_{4}+3.06 \mathrm{x}_{6}+0.68 \mathrm{x}_{6}$ & 9.40 & $50 \%$ \\
\hline \multicolumn{4}{|c|}{ Reactivities with steam } \\
\hline 1 & $\mathrm{y}=1.18 \mathrm{x}_{1}+0.76 \mathrm{x}_{2}+0.25 \mathrm{x}_{3}-2.07 \mathrm{x}_{4}+3.70 \mathrm{x}_{6}-0.26 \mathrm{x}_{6}+3.34$ & 5.00 & $10 \%$ \\
\hline 2 & $y=7.99 x_{1}+7.36 x_{2}+6.92 x_{3}+4.32 x_{4}+8.65 x_{5}+6.27 x_{6}-3.17$ & 6.04 & $20 \%$ \\
\hline 3 & $\mathrm{y}=7.30 \mathrm{x}_{1}+6.59 \mathrm{x}_{2}+6.06 \mathrm{x}_{3}+3.56 \mathrm{x}_{4}+7.52 \mathrm{x}_{5}+5.25 \mathrm{x}_{6}-2.34$ & 6.63 & $30 \%$ \\
\hline 4 & $\mathrm{y}=3.96 \mathrm{x}_{1}+3.12 \mathrm{x}_{2}+2.21 \mathrm{x}_{3}+0.16 \mathrm{x}_{4}+4.22 \mathrm{x}_{5}+1.68 \mathrm{x}_{6}+0.99$ & 7.08 & $50 \%$ \\
\hline 5 & $\mathrm{y}=4.32 \mathrm{x}_{1}+4.14 \mathrm{x}_{2}+3.45 \mathrm{x}_{3}+1.11 \mathrm{x}_{4}+6.29 \mathrm{x}_{5}+3.44 \mathrm{x}_{6}$ & 4.70 & $10 \%$ \\
\hline 6 & $\mathrm{y}=4.65 \mathrm{x}_{1}+4.27 \mathrm{x}_{2}+3.50 \mathrm{x}_{8}+1.17 \mathrm{x}_{4}+5.85 \mathrm{x}_{8}+3.37 \mathrm{x}_{6}$ & 5.55 & $20 \%$ \\
\hline 7 & $\mathrm{y}=4.82 \mathrm{x}_{1}+4.31 \mathrm{x}_{2}+3.50 \mathrm{x}_{3}+1.11 \mathrm{x}_{4}+5.68 \mathrm{x}_{6}+3.13 \mathrm{x}_{6}$ & 6.05 & $30 \%$ \\
\hline 8 & $\mathrm{y}=4.95 \mathrm{x}_{1}+4.18 \mathrm{x}_{2}+3.35 \mathrm{x}_{3}+0.89 \mathrm{x}_{4}+5.75 \mathrm{x}_{6}+2.65 \mathrm{x}_{6}$ & 6.67 & $50 \%$ \\
\hline
\end{tabular}

$\mathrm{x}_{1}=$ Content of isotropic texture, $\mathrm{x}_{2}=$ Content of fine mosaic texture, $\mathrm{x}_{3}=$ Content of coarse mosaic texture, $\mathrm{x}_{4}=$ Content of fibrous texture, $\mathrm{x}_{\mathbf{8}}=$ Content of leaflet texture, $\mathrm{x}_{8}=$ Content of inert texture, $\mathrm{y}=$ Reactivity of coke,

Eqs. 1- 4 : according to normal regression analyses,

Eqs. 5- 8: according to method of least squares on the assumption that constant term is zero, Eqs. 9-12: on the two assumptions that constant term is zero and that all of the coefficients are not minus.

の小さいフラクションであり, 瀝青炭の場合にはその 加熱溶融性を支配するフラクションである。したがっ て揮発分の離脱の抑制は流動性の増大を, 逆に揮発分 離脱の促進は流動性の低下をもたらすことが考兄られ る。もしそらであるならば，加圧炭化では matrix の 流動性は固化直前まで常圧炭化時のそれより高く維持 され, 減圧炭化時には逆に溶融性成分が失われて matrix の粘度が急速に高まることが推定できる。炭化 時に加圧すれば， matrix 構成分子の重縮合反応も促 進され, 重縮合分子の平面構造の広がりも拡大し, 重 層構造を形成しやすい分子へ成長することも期待でき よう。こうして加圧炭化の場合には重層構造の形成が
助長促進され, 光学的異方性組織の良く発達したコー クスが得られる。これに対して減圧炭化の場合には, 状況はまったく逆となり, 光学的異方性組織の発達は 阻害される。

コークスの気孔構造は，基本的には溶融時の流動性 と揮発分発生のバランス, 拈よび再固化後の揮発分離 脱による収縮亀裂の生成によって定まる ${ }^{14)}$ 。さらに敷 行すれば気孔の大きさと炭化の過程とを対応させても デル機構を考えることができる。最高流動度を過ぎる までは石炭分子の重縮合も不十分で, 高分子化の程度 も低く，比較的流動性の高い石炭の場合だと matrix の粘度もまだ低い。したがって発生したガスは容易に 
matrix の外に放散されて気孔の生成はあ⿱りない。 炭化が進行し高分子化が進めば matrix は粘稒となり, 発生ガスの放散が妨害されて matrix 内に包含され, 気孔の生成となる。この段階で生成する気孔は比較的 大きいと考觉られる。さらに炭化が進み, matrix の 粘稠度が高采る固化直前から固化要での期間にも気泡 の発生があるが，その成長は matrix の高い粘税性に 阻止されて細かい気孔の生成となる。これよりさらに 微細な気孔の生成は, 固化後のガス発生によるコーク スの収縮に基ずく龟裂の発生がその主因と考兄られ る。コークスの BET 比表面積については, この偖裂 を生因とする微細気孔の多塞が大きな支配要因とな る。三池炭コークスのよらに大きな気孔を持つポーラ スな構造は, matrix の粘稠性が比較的低い状態で多量 の揮発分を放出する炭化過程で得られ, 強粘結炭コー クスのように激密な構造を持つコークスは, matrix の 粘稠性が高く, 揮発分が少量のため微細気孔の生成に 適した状態で炭化されたコークスの典型である。

気孔容積は常圧炭化と減圧炭化コークスの間では差 が認められないが，加圧炭化コークスでは明らかな増 大傾向が認められる。特に Caribbean, Saraji, Beatrice のように, 石炭化度に比較して膨張性の高い強粘結炭 で著しい。加圧によって炭化末期まで matrix の粘稠 度が下がり, 比較的大きな気泡が多量に発生して気孔 容積の增大を招いたとして理解できよう。一方紬孔 $(50 \mu \mathrm{m} \sim 50 \AA)$ の容積にはこのような炭化圧力との一 定関係虫られないことも上述の機構化合致する。

三池炭はもともと加熱溶融時の流動性がきわ立って 高く, 常圧炭化でも matrix の粘度は非常泜い。乙 たがって加圧炭化しても，コークスの気孔容積の增大 はそれ程大きくはない。逆に加圧炭化によって細孔容 積は極端に小さくなって和り, matrix の高粘稠期間が 短かかったことを意味している。Peak Downs 炭では 気孔容積, 細孔容積ともに炭化圧力の影響はなく, い ずれも大きな值を示している。つまり， 3 種の圧力下 で, 打の扮の matrix の粘度とガス発生とがバランス し, 物理構造が変化しないと推測される。

一般に細孔容積は石炭化度の上昇に伴なってしだい に大きくなっていく傾向が認められるが，これは石炭 化度の上昇とともに石炭構成分子のサイズが大きくな り, それにつれて matrix の粘稠度が増す結果である 亏。

減圧炭化コークスの細孔容積は, 石炭化度の低い三 池と Lemington でかなり増大しているのが認められ る。これらの石炭では減压によって matrix の粘稠度
が増し，多量の揮発分発生により細孔容積が増大した

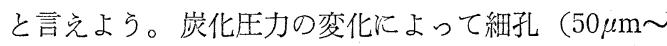
$50 \AA$ ) の容積はあまり影響を受けないが，この範团の 細孔の比表面積は隇圧炭化コークスで著しく増してい る。つ导り数百 $\AA$ 以下の細孔だけが增大しているので 西万弓。

\section{2 ガス化反応性}

コークスのガス化反応には，反応温度の上昇にした がって化学反応律速, 気孔拡散律速, 境莫拡散律速の 領域が苛り，その温度範囲は $\mathrm{CO}_{2}$ との反応では一般 に $1100^{\circ} \mathrm{C}$ 以下, $1100 \sim 1300^{\circ} \mathrm{C}, 1300^{\circ} \mathrm{C}$ 以上とされてい るが ${ }^{15)}$, 本研究での反応温度は化学反応律速から気孔 拡散律速への遷移段階嘱すると思われる。したがっ て光学的異方性組織で代表されるようなコークス炭素 質の化学的な反応性の湾かに, 気孔分布のよらな物理 的性状の影響が大きい。

いくつかの例外的な数值を除殀，同一原炭から得 られたコークスの各光学的組織の反応性は比較的近似 した值を示して和り，基本的には各光学的組織ごとに 個有の反応性があると考えてょからう。ただ物理的性 状の相違などにより，その值に差が生ずるるのと考兄 られる。さらに炭種間の差を無視して各光学的組織の

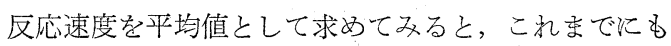
指摘されているように，異方性の発達とともに反応性 が低下する傾向は㫜りようで, $\mathrm{CO}_{2}$ との反応性, $\mathrm{H}_{2} \mathrm{O}$ との反応性ともに光学的組織の反応性は, イナート組 織〉等方性組織>徽粒モザイク組織〉粗粒モザイク組 織二葉片状組織〉繊維状組織の順となっている(Table 4)。

炭化圧力の上昇に伴なってコークスの光学的異方性 が発達し，その反応性も低下するという傾向は，流動 性の低い石炭のコークスで顕著で耑った。しかし流動 性の高い石炭のコークスでは, 加圧炭化コークスの光 学的異方性は良く発達するにもかかわらず，先の反応 性はか觉って高くなっていることからみて, 光学的組 織以外の物理的構造, すなわち気孔容積, 比表面積の ようなコークス内部での反応ガスの拡散に関与する物 理的性状がコークスのガス化反応性に影響しているこ とがうかがわれる。たとえば三池, Caribbean, Saraji, Beatrice の加圧炭化コークスの反応性が常圧炭化コー クスのそ机より高いのは，加圧炭化コークスの気孔容 積がきわ立って大きく、 コークス内部での反応ガスの 拡散が容易であることがその一因と考劣られる。

同じ光学的組織であっても，異炭種間になるとその 反応性もかなり異なり,コークス全体の反応性の高低 
に追随する傾向が認められる。回帰分析の場合, 各光 学的組織の反応性指数に対し, コークス全体の反応性 が大きく影響する。イナート組織は同じコークス内で は最も反応性が高く, どのコークスでも最初に消失す る組織である。ところが回帰分析の結果では非常に低 い反応性指数が算出された。前報 ${ }^{(8)}$ 亿も述べたよう に, コークスの反応性はイナート組織の含有量と逆相 関の関係があって, イナート組織の多いコークスほど 反応性が低い関係にある。すなわち、イナート組織自 身の反応性は確か汇高いが, 石炭化度支配領域 ${ }^{16)}$ 飞和 いてはイナート組織の存在がコークス全体の反応性を 下げ，回帰分析の結果に反映するものと考光られる。 イナート成分は流動成分の炭化に介入し, 気孔の少な いコークスを与える結果となる。このことがコークス 全体としての反応性を低める効果をもたらしているの であろう。

葉片状組織は Saraji と Beatrice コークスにしか存 在しない。どちらも石炭化度の高い, 膨張性の大きい 石炭で, その加圧炭化コークスは光学的異方性も若干 上昇し, 葉片状組織も増加するが, それ以上に気孔容 積が大きく増大し, その結果コークスのガス化反応性 が高くなる炭種である。したがって葉片状組織の増加 がコークスの反応性の上昇につながる。葉片状組織が この 2 炭種のコークスにしか含をれていないため, 回 帰分析の結果では葉片状組織の反応性指数が大きくな って，I法による実測值より大きな数値となっている のであろう。

\section{5. むす び}

異なる圧力の下に石炭を炭化し, 光学的異方性組織 を修飾した 30 種のコークスを得た。これらのコークス を用いて, 光学的組織の反応速度を実測ならびに回㷌 分析によって求めた。実測結果に上れば，同一原炭の コークスの光学的組織は比較的近似した值で方った が，異炭種間ではかなりの差が認められた。コークス の反応性には，その物理構造が大きく作用して祘り，
今後はこの点の解明が必要である。

最後に, 本研究を進めるに当たり, 九州大学生産科 学研究所の竹下健次郎教授, 持田勲助教授に有益な御 助言をいただいたことなならびに三井鉱山侏システム 室の黒田望氏に回帰式の算出に御協力いただいたこと を付記して感謝いたします。

\section{文献}

1）神原, 小島, 山口, 仲摩, 井田, 鉄と鋼, 61, S 28 (1975)

2）小島, 西, 山口, 仲摩, 井田, 鉄と鋼, 62, 570 (1976)

3）山口, 奥原, 古井, コークスサーキュラー, 23, 261 (1974)

4）角南, 小川, コークスサーキュラー，26，262 (1977)

5）宮川，嵯峨，谷原，燃然誌，56，337（1977）

6）井田，木庭，山下，坂田，コークスサーキュラ 一, 27, 261 (1978)

7）木庭, 坂田, 井田, コークスサーキュラー, 28, 311 (1979)

8) K. Koba and S.Ida, Fuel, 59, 59 (1980)

9）藤田，聖山，西田，第68回燃料協会コークス特別 会予稿集, 10 (1980)

10) H. Marsh, F. Dachille, J. Melvin and P.L. Walker Jr., Carbon, 9, 159 (1971)

11) H. Marsh, J.M. Foster, G. Hermon and M. Iley, Fuel, 52, 234 (1973)

12) P.H. Emett and S. Brunauer, J. A.Chem. Soc., 59, 1553 (1937)

13) H. Marsh, Fuel, 52, 205 (1973)

14) D. Hays, J.W. Patrick and A. Walker, Fuel, 55, 297 (1976)

15) E. W. Thiele, Ind. Eng. Chem., 31, 916 (1939)

16）第15回鉄鋼協会コークス部会資料, 日本鋼管(侏報 告（1977）11月30日～12月 2 日 


\title{
Optical Anisotropic Textures and Gasification Reactivities of Cokes
}

\author{
Keiichiro KoBA, Koji SAKATA and Shiro IDA
}

\section{(Mitsui-Mining Co.,)}

SYNOPSIS : - Ten coals were carbonized under various pressures $(30 \mathrm{mmHg}$, normal pressure and $100 \mathrm{~kg} / \mathrm{cm}^{2}$ ), optical anisotropic textures of their cokes being modified. The extent of optical anisotropy increased greatly with increasing carbonization pressure, such a trend being significant with lower rank coals. The physical structures were also influenced by the carbonization pressure. Gasification reactivities of the cokes with carbon dioxide and steam $\left(1,200^{\circ} \mathrm{C}\right)$ were tried to correlate with their optical anisotropy and physical structure. Gasification reactivities of respective optical textures were estimated by both point-counting technique and regression analysis. Reactivities of the same optical textures in the cokes produced from the same parent coal were roughly same, however they considerably diverse when compared as for different parent coals. Although the values estimated by regression analyses were consistent to those by the point-counting except for those of leaflet and inert texture, the physical situations of respective textures were deduced to be important for the quantitative discussion of their reactivities. 